\title{
MENAKAR EFEKTIFITAS PROGRAM AFLATOUN DALAM PENDIDIKAN KARAKTER
}

\author{
Mufiqur Rahman
}

(STAI Al-Khairat Pamekasan)

\begin{abstract}
Abtsrak:
Program Aflatoun adalah program pendidikan sosial dan finansial untuk anak. Lembaga ini berfokus pada pembelajaran tentang tanggung jawab sosial dan pendidikan finansial yang diselenggarakan dalam lingkup pendidikan formal dan non-formal. Tujuan utama pembelajarannya adalah membangun hak dan tanggung jawab yang memungkinkan individu untuk mengembangkan komunitas mereka dengan teliti. Program ini menginspirasi anak memberdayakan diri secara sosial dan finansial untuk menjadi agen perubahan dalam kehidupan mereka sendiri dan dunia yang lebih adil. Dengan demikian, Aflatoun berusaha mewujudkan anak untuk menjadi inspirasi bagi lingkungannya. Aflatoun merupakan sebuah organisasi non-pemerintah lintas negara yang memberikan perhatian besar kepada pendidikan anak melalui organisasiorganisasi non-profit di dunia. Di Indonesia, program ini dilaksanakan oleh Lekdis Nusantara yang aktif menyelenggarakan sosialisasi dan pelatihan/workshop aflatoun di berbagai daerah. Penelitian ini akan melihat manfaat dan tawaran apa saja yang diberikan untuk menumbuh kembangkan pendidikan ke arah yang lebih baik. Sehingga, program ini dapat diterima sebagai salah satu alternatif dalam memberikan solusi berbagai isu pendidikan yang kian kompleks.
\end{abstract}

Kata Kunci : Program, Aflatoun, Pendidikan, Karakter. 


\begin{abstract}
:
Aflatoun is a social and financial education program for children. The program focuses on social responsibility and financial education which is organized in both formal and non-formal education. The main purpose of learning is to establish rights and responsibilities to enable individuals in developing their communities. This program inspires children to socially and financially develop themselves in order to be agents of change in their own lives and better world. In other words, Aflatoun promotes children as the inspiration for their environment. Aflatoun is a transnational non-governmental organization which pays a great attention to children education via non-profit organization in the world. In Indonesia, the program is implemented by Lekdis Nusantara and actively organizes socialization, training, and workshops in various under represented areas. This study examines benefits and opportunities given to cultivate education to a better direction. Thus, this program can be accepted as an alternative way in providing solutions for increasingly complex issues in education.
\end{abstract}

\title{
Keywords: Program, Aflatoun, Education, Character.
}

\section{A. Pendahuluan}

Alqur'an banyak berbicara tentang pendidikan akhlak, watak, karakter dan budi pekerti. Salah satunya dalam surah Luqman ayat 18-19 yang menerangkan lanjutan wasiat Luqman kepada anaknya, yaitu agar anaknya berbudi pekerti (berkarakter) yang baik:

"Dan janganlah kamu memalingkan mukamu dari manusia (karena sombong) dan janganlah kamu berjalan di muka bumi dengan angkuh. Sesungguhnya Allah tidak menyukai orang-orang yang sombong lagi membanggakan diri. Dan sederhanalah kamu dalam berjalan dan lunakkanlah suaramu. Sesungguhnya seburuk-buruk suara ialah suara keledai." Q.S:1 Luqman/31:18-19.

Pendidikan adalah usaha sadar dan terencana untuk mewujudkan suasana belajar dan proses pembelajaran agar peserta didik secara aktif mengembangkan potensi dirinya untuk memiliki kekuatan spritual keagamaan,

${ }^{1}$ Departemen Agama RI , Al-Qur'an dan Terjemahannya (Bandung: CV Penerbit J-ART, 2007) 
pengendalian diri, kepribadian, kecerdasan, akhlak mulia, serta keterampilan yang diperlukan dirinya, masyarakat, bangsa dan Negara. ${ }^{2}$

Pendidikan Nasional berfungsi mengembangkan kemampuan dan membentuk watak serta peradaban bangsa yang bermartabat dalam rangka mencerdaskan kehidupan bangsa, bertujuan untuk berkembangnya potensi peserta didik agar menjadi manusia yang beriman dan bertakwa kepada Tuhan Yang Maha Esa, berakhlak Mulia, sehat, cakap,kreatif, mandiri, dan menjadi warga Negara yang demokratis serta bertanggung jawab. ${ }^{3}$

Secara jelas Undang-undang Sistem Pendidikan Nasional menyebutkan perkembangan berbagai karakter sebagai tujuannya, seperti beriman, bertakwa berakhlak mulia, kreatif, mandiri, dan menjadi warga negara yang demokratis dan bertanggung jawab. Namun praktik pendidikan formal di sekolah-sekolah yang berlaku umum di Indonesia sekarang ini, yang mencakup suasana, proses, subtansi dan penilaian hasil pembelajaran, belum menunjukkan adanya usaha yang sungguh untuk mencapai tujuan pendidikan yang berdimensi karakter tersebut. Di samping itu, Indonesia dan masyarakat dunia sekarang ini mengalami masalah-masalah besar yang sangat berkaitan atau bersumber pada karakter. ${ }^{4}$

Berdasar pada Undang-undang tersebut maka Negara dalam perjalanannya akan terus berupaya untuk selalu melakukan berbagai terobosan untuk meningkatkan nilai pendidikan bangsa untuk membentuk watak dan martabat bangsa dalam kancah dunia. Salah satunya dengan terjadinya perubahan-perubahan dalam sistem pendidikan Nasional. Hal ini menerangkan keyakinan bahwa Negara Indonesia sampai saat ini tengah mencari dan berbenah sehingga Pendidikan Nasional betul-betul pada fungsi dan tujuannya.

Pendidikan kini terus berubah, berkembang dan bertambah kompleks, bahkan tumbuh tidak berbanding lineir dengan masalah anak manusia. Dalam pendidikan ada pendidik, ada perencanaan, ada strategi, ada media, ada evaluasi. Sebagian orang ada yang mendalami strategi selalu membuat penelitian agar mendapatkan startegi alternatif yang lebih efektif. Sementara yang lain ada yang mengembangkan media untuk menjadikan pembelajaran agar lebih mudah. Begitupun ada sebagian kita yang mendalami evaluasi agar anak lebih siap mengikuti kegiatan pendidikan tanpa takut dengan ujian. ${ }^{5}$

2 Undang-undang RI nomor 20, tahun 2003, tentang Sistem Pendidikan Nasional baba I pasal 1 ayat 1 .

${ }^{3}$ Undang-undang RI nomor 20, tahun 2003 tentang Sistem Pendidikan Nasional bab 2 pasal 3.

${ }^{4}$ Gede Raka, et. al.,Pendidikan Karakter di Sekolah : dari gagasan ke tindakan, (Jakarta: PT Alex Media Komputinduo Kelompok Gramedia, 2011). h. 20-21.

${ }^{5}$ Mardianto, Teknik pengelompokan siswa (Medan: IAIN Press, 2013), h. 5.

Jurnal Pendidikan Agama Islam

Volume 3 Nomor 2 November 2015

ISSN: 2089-1946

Hal. 420 - 449 
Pada saat yang sama, berbagai macam program pengembangan model pendidikan mulai ditawarkan, baik dari dalam maupun dari luar Negeri. Salah satunya yang masih hangat dan baru-baru ini masuk ke Negara Indonesia adalah Pola pendidikan yang ditawarkan oleh Program Aflatoun.

Aflatoun adalah program pendidikan sosial \& finansial yang seimbang untuk anak. Belajar tentang tanggung jawab sosial dan pendidikan finansial yang dibawa ke dalam lingkup pendidikan formal dan non-formal. Pendidikan Sosial \& finansial untuk anak, mengembangkan dua lintasan utama belajar: pemahaman tentang hak dan tanggung jawab yang memungkinkan individu untuk mengembangkan komunitas mereka dengan teliti. Pengetahuan dan keterampilan yang memungkinkan individu untuk membuat penggunaan terbaik dari sumber daya yang tersedia 6

Aflatoun yang merupakan sebuah organisasi non pemerintah (non governmen organization/NGO) lintas negara yang memberikan perhatian besar kepada pendidikan anak ${ }^{7}$ organisasi non profit ini berkembang pesat hingga ke seluruh negara di dunia, termasuk Indonesia.

Di Indonesia pertama kali diimplementasikan oleh LAPIS-AusAID/LeKDiS Nusantara \& menjadi Negara ke 34 Sekarang Aflatoun berkembang menjadi beberapa kurikulum, diantaranya; Aflatot (anak pra-sekolah), Aflatoun (usia 614 tahun), Aflateen (usia 15 - 18 tahun atau lebih), dan Afla Academy (untuk mahasiswa, guru, fasilitator dan mentor). Setelah program LAPIS berakhir maka Program Aflatoun terus dikembangkan oleh LeKDiS Nusantara dan sudah mencapai 56 kab/kota di 9 provinsi; Jatim, Jateng, Jabar, Jakarta, Sumatera Utara, Kalimantan Selatan, Kalimantan Timur, aceh dan NTB. ${ }^{8}$

Dalam konteks Indonesia, Program Aflatoun akan beranah dalam lingkup pendidikan karakter. Sehingga Implementasi Program Aflatoun di Indonesia rasanya sangat berkontribusi cukup baik dalam membantu keberlangsungan proses pendidikan karakter yang tengah menjadi tujuan dari pada sistem Pendidikan Nasional. Bung Karno sebagai salah satu bapak pendiri bangsa (founding fathers) dalam berbagai kesempatan mengingatkan bangsa Indonesia akan pentingnya nation and character building. Pembangunan watak bangsa sangat diperlukan mengingat bangsa Indonesia sangat heterogen dan memiliki

\footnotetext{
${ }^{6}$ Sekretariat Aflatoun, "Aflatoun Programme Note"dalam Aflatoun Magazine (20 September 2012), h. 2. Lihat juga dalam Tim Pengembang Aflatoun Indonesia, Aflatoun Evaluation Manual, terj. Lapis (Program for Islamic school supported by Australian Governmen), Manual Evaluasi Aflatoun (Jakarta: Lekdis Nusantara, Lembaga Kajian Pendidikan, Keislaman dan sosial Nusantara, 2008), h.84.

7 Suryadi, "Aflatoun Berjuang Cerdaskan Anak Negri" dalam Harian Radar Madura (Jawa Pos Group), 19 Maret 2013. h. 2

8 Suryadi, Koordinator Aflatoun Indonesia, Wawancara di Medan, tanggal 23 Oktober 2010.
} 
kemajemukan, tidak hanya bersifat horisontal tetapi juga bercorak vertikal. Dengan karakter yang tangguh, bangsa Indonesia akan dapat berdiri sejajar dengan bangsa lain, bahkan bukan tidak mungkin dapat melampaui kemajuan bangsa lain. ${ }^{9}$

Aflatoun tengah menawarkan pendidikan bermutu dan menjadi penting untuk didayagunakan di bumi pertiwi ini. Sebagaimana semua warga berhak mendapat layanan pendidikan bermutu. ${ }^{10}$ Hal ini menjadi target dan tujuan Program Aflatoun yaitu semua anak muda harus terpenuhi hak-haknya, hak Pendidikan, kasih sayang, perlindungan, ruang kreatifitas dan partisipasi yang memungkinkan anak mencapai impian terbesar mereka, menjadi agen perubahan bagi dirinya sendiri, masyarakat dan dunia.

Dengan diterapkannya Program Aflatoun di Negara-negara mayoritas Muslim di antaranya seperti Mesir, Arab Saudi, Banglades, Pakistan, Afganistan, Malaysia dan Indonesia mengindikasikan suatu keserasian dan kesamaan makna, tujuan dan nilai Program Aflatoun dengan Pendidikan Karakter Nasional.

Banyaknya pelatihan-pelatihan, workshop maupun seminar tentang Implementasi Program Aflatoun di sekolah dan Pesantren sejak tahun 2012 di berbagai lembaga pendidikan di Indonesia, di antaranya diselenggarakan di Nusa Tenggara Barat, Jawa Timur, Jawa Tengah, Jawa Barat, Kalimantan Timur, Kalimantan Selatan, dan Sumatera Utara dan Aceh. ${ }^{11}$ Menciptakan sebuah pengertian akan pentingnya program ini.

\section{B. Kajian Teori}

\section{Sejarah Singkat Program Aflatoun}

Aflatoun dimulai di Mumbai India, di mana pada tahun 1991 sebagai sebuah proyek penelitian tindakan oleh Jeroo Billimoria, bekerja di Tata Sekolah Ilmu Sosial. Mereka mulai bekerja sama dengan sekolah untuk membawa anak-anak kaya dan miskin bersama-sama belajar tentang kehidupan satu sama lain.

Pada tahun 1993 program ini berperan penting dalam mengajarkan moral lebih luas ketika kerusuhan antar etnis mengguncang Mumbai. Program ini merespon dengan berfokus pada memerangi prasangka dan diskriminasi melalui pendidikan hak. Ekspansi ke luar kota dan ke wilayah pedesaan menyebabkan pengaruh kunci lain. Anak-anak wirausahawan

\footnotetext{
${ }^{9}$ Eko Handoyo \& Tijan, Model Pendidikan Karakter (Semarang: Widya Karya Press, 2010), h.1.

${ }^{10}$ Lihat Undang-undang Sisdiknas 2003 Bab V pasal 1 tentang hak dan kewajiban warga neggara. bahwa semua warga Negara mempunyai hak yang sama untuk memperoleh pendidikan yang bermutu.

${ }^{11}$ Suryadi, Juknis Pelaksaan Pelatihan Program Aflatoun untuk guru SD \& Mts di Medan tahun 2012 (buku, tidak diterbitkan), h.1.
} 
meninggalkan negara itu dan menjadi anak jalanan dan pekerja di Mumbai. Untuk memanfaatkan energi dan kreativitas mereka di rumah, didirikan sekelompok untuk memulai menabung sejak tahun 2001.

Aflatoun adalah jaringan organisasi mitra global yang mengimplementasikan program pada target sasaran. Mitra tersebut meliputi organisasi besar seperti UNICEF, LSM besar seperti Plan International, ChildFund, Children International and Mercy Corps, dan banyak LSM kecil berskala lokal. Sejak akhir 2012 Aflatoun memulai proyek mitra dengan Pusat Pelatihan Guru. ${ }^{12}$

Sekretariat Aflatoun, tim internasional yang bekerja di kantor di Amsterdam yang dipimpin oleh seorang Direktur Eksekutif. Ada beberapa manajer program bagi setiap daerah berikut; Timur Tengah dan Afrika Utara, Francophone Afrika, Afrika yang berbahasa Inggris,Eropa, Asia dan America.

Sekretariat menyusun dan mengembangkan materi pendidikan. Materi tersebut adalah 'sumber terbuka'. Contoh, ketika sebuah organisasi menandatangani perjanjian kemitraan dengan Aflatoun, salinan dari buku tersebut diberikan secara gratis. Secretariat juga melaksanakan program pelatihan bagi mitra, melakukan penelitian dan mempunyai tim komunikasi. Sekretaria tidak mendanai organisasi mitra secara langsung. Akan tetapi secretariat menjembatani mereka pada donor dana dan kadang-kadang menawarkan bantuan teknis dalam hal penulisan proposal.

Setiap dua tahun ada Pertemuan Regional di setiap enam daerah tersebut. Organisasi mitra berkumpul untuk berbagi pengalaman, memberikan saran dan menerima pelatihan. Dan juga untuk menikmati masing-masing perusahaan dalam setting sosial! Pada tahun 2008 Pertemuan Regional di Afrika, pada tahun 2010 dilaksanakan di Ghana dan pada tahun 2012 diselenggarakan di Ethipia. Setiap beberapa tahun semua mitra Aflatoun dari seluruh dunia berkumpul pada Pertemuan Internasional. Pada tahun 2007 Pertemuan Internasional dilaksanakan di Amsterdam, tahun 2009 diselenggarakan di Mesir, tahun 2011 dilaksanakan di Belanda dan dilaksanakandi Nairobi dari 1 - 3 July.

Ada satu cara menggunakan keahlian teknik dari organisasi mitra dalam bagian utama di bawah ini:
a. Pengembangan Kurikulum
b. Penilaian Akibat
c. Partisipasi Anak

12 Tim penyusun manual pelatihan aflatoun, ( Lekdis Nusantara, tt.tp), h.164 
d. Jaminan Kualitas

Tenaga tugas ini biasanya bertemu sekali atau dua kali dalam setahun di Amsterdam.

Pada era globalisasi yang dimulai pada 2005 ketika Aflatoun (Tabungan untuk Anak Internasional) didirikan di Amsterdam, sekarang menjadi social entrepreneur yang diakui secara global, dan Skoll Foundation mendapat penghargaan sebagai yayasan untuk membawa pendidikan sosial dan keuangan dunia. Untuk menguji apakah program tersebut akan bekerja di luar India, organisasi meluncurkan program di sepuluh negara. Setelah model Program Aflatoun dikembangkan, Kampanye untuk Pendidikan Sosial dan Keuangan diluncurkan pada bulan Maret 2008 oleh Putri Maxima dari Belanda. Tujuan ambisius kampanye adalah untuk mencapai satu juta anak di 75 negara dalam waktu tiga tahun dan target-target ini terlampaui.

Pada tahun 2011, Aflatoun memperluas menawarkan kurikulum dengan menyediakan sebuah program untuk pemuda yang disebut Aflateen . Hal ini juga mengumumkan bahwa sasaran strategis baru akan menjadi 10 juta anak dicapai pada 2015.13

\section{Gambar 1 Aflatoun di Dunia}

13 http://www.Aflatoun.org/story/story-selected/Aflatoun-comes-from, diakses Jumat 25 Oktober 2013 pukul 18.30 WIB 


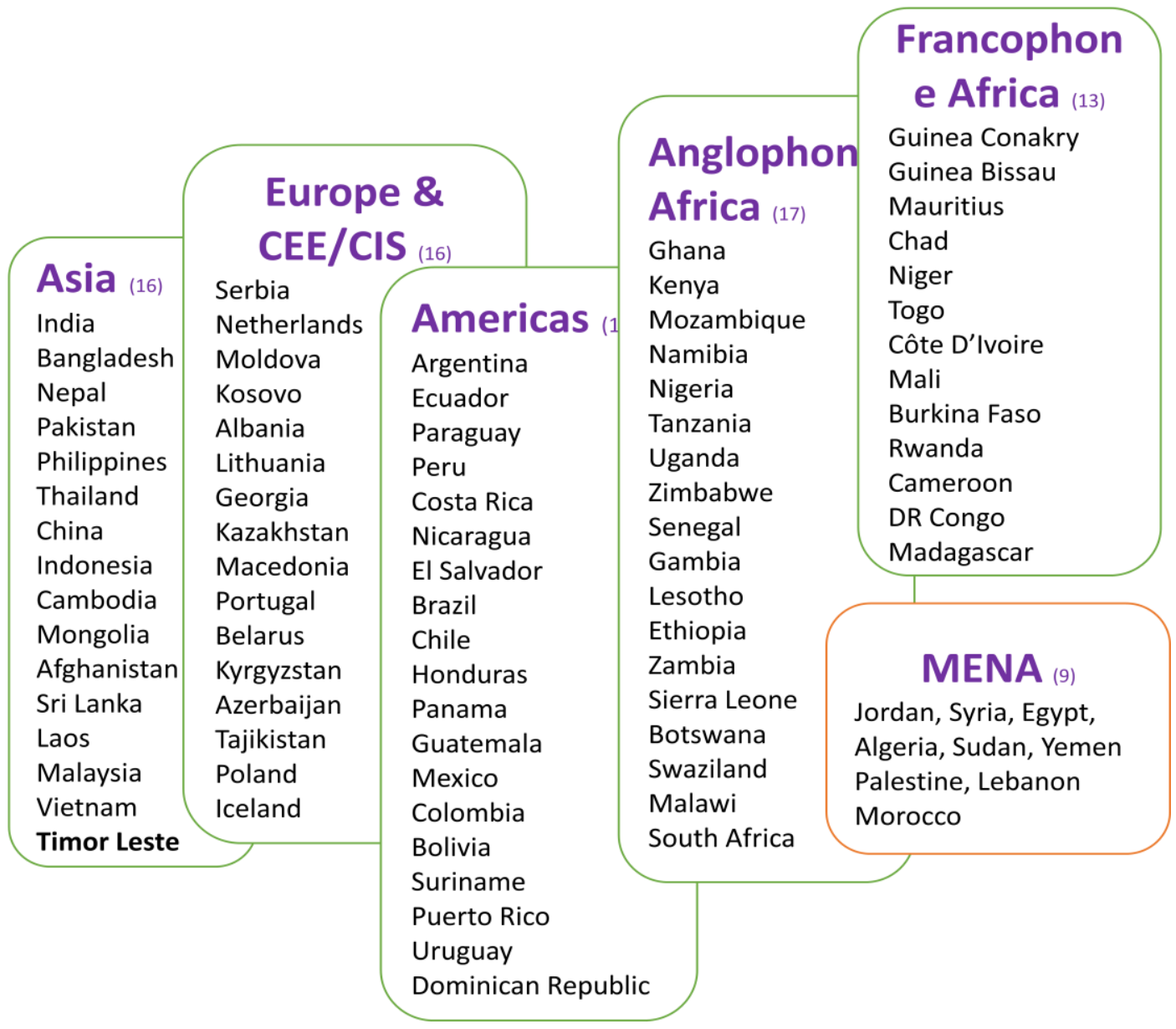

\section{Hakikat dan Tujuan Implementasi Program Aflatoun}

Kata implementasi secara etimologi diartikan sebagai pelaksanaan atau penerapan. ${ }^{14}$ Sedangkan Program berarti rancangan mengenai asas serta usaha yang akan dijalankan. ${ }^{15}$ Ada dua pengertian untuk istilah "Program" yang pertama adalah pengertian secara khusus dan yang kedua adalah pengertian secara umum. Program dapat diartikan sebagai rencana. Jika seorang siswa ditanya oleh guru, apa programnya sesudah lulus dalam menyelesaikan pendidikan di sekolah yang diikuti maka arti "Program" dalam kalimat tersebut adalah rencana atau rancangan kegiatan yang akan dilakukan setelah lulus. Rencana ini mungkin berupa keinginan untuk

14 Departemen Pendidikan dan Kebudayaan, Kamus Besar Bahasa Indonesia (Jakarta:Balai Pustaka, 1996), h. 785.

15 Tim Redaksi, Kamus Besar Bahasa Indonesia (Jakarta: Balai Pustaka, 2001), Edisi Ketiga. h.897. 
melanjutkan ke pendidikan yang lebih tinggi, mencari pekerjaan, membantu orang tua dalam membina usaha, atau juga mungkin belum menentukan program apapun. Selain itu, ada juga anak yang sangat tergantung pada orangtua sehingga akan memberi jawaban bahwa program masa depan menunggu keputusan orang tuanya. ${ }^{16}$

Apabila program ini langsung dikaitkan dengan evaluasi program, maka program definisikan sebagai suatu unit atau kesatuan kegiatan yang merupakan realisasi atau implementasi dari suatu kebijakan, berlangsung dalam proses yang berkesinambungan, dan terjadi dalam suatu organisasi yang melibatkan sekolompok orang. Ada tiga pengertian penting dan perlu ditentukan dalam menentukan program, yaitu : 1. Realisasi atau implementasi suatu kebijakan, 2. Terjadi dalam waktu relatif lama-bukan kegiatan tunggal tetapi jamak-berkesinambungan, dan 3. Terjadi dalam organisasi yang melibatkan sekelompok orang. ${ }^{17}$

Program Aflatoun berarti pendekatan teruji dan bertujuan untuk memberdayakan anak-anak melalui sebuah pendekatan berimbang terhadap pendidikan sosial dan finansial anak (PSFA). ${ }^{18}$ Sedangkan kata Aflatoun diambil dari Kata Bahasa arab yaitu Plato (427-347 SM) ${ }^{19}$.

Program Aflatoun adalah sebuah jaringan yang tumbuh cepat guna mencapai tujuan 2010 untuk melaksanakan program-program berkualitas Aflatoun di 75 Negara, dengan mencapai satu juta anak-anak sebelum 2010.20

Program Aflatoun ini berisi tema sosial dan keuangan. Anak-anak belajar tentang diri mereka sendiri, hak-hak anak, tabungan, konsep keuangan dasar, dan perusahaan. Aflatoun menempatkan anak di tengahtengah proses belajar mereka dan melibatkan mereka dengan dunia di sekitar mereka. Dengan demikian, Aflatoun percaya bahwa pelajaran sosial dan keuangan yang mereka terima akan tinggal bersama mereka selamanya.

16 Suharsimi Arikunto dan Cepi Safruddin Abdul Jabar, Evaluasi Program Pendidikan (Jakarta: PT Bumi Aksara, ,2004), cet.1.h.2.

17 Ibid.,h.3.

18 Sekretariat Aflatoun Indonesia, Manual Evaluasi Aflatoun, terj. Lapis (Program for Islamic school supported by Australian Governmen), Manual Evaluasi Aflatoun (Jakarta: Lekdis Nusantara, Lembaga Kajian Pendidikan, Keislaman dan sosial Nusantara, 2008), h.3.

19 Salah satu filosof Yunani yang mashur, ia merupakan murid dari Socrates dan guru Aristoteles. Lihat Abdullah al-alayali dan Saayyid Hasan al-Amien, Munjid fi al-A'lam (Bairut: Darul Masyriq, 1998). Cet. 23. h.58.

${ }^{20}$ Sekretariat Aflatoun Indonesia, Manual Evaluasi Aflatoun, h.3.

Jurnal Pendidikan Agama Islam

Volume 3 Nomor 2 November 2015

ISSN: 2089-1946

Hal. 426 - 449 
Sedangkan kurikulum Aflatoun berisi tema sosial dan keuangan. Anak-anak belajar tentang diri mereka sendiri, hak-hak anak, bagaimana cara menyimpan, dan bagaimana konsep dasar keuangan, dan perusahaan .

Prinsip pengajaran yang digunakan dalam program Aflatoun disebut pembelajaran yang berpusat pada anak (student oriented). Anak-anak diberi ruang untuk mengekspresikan diri, untuk bertindak sendiri, dan untuk memecahkan masalah praktis secara bersama-sama .

Mereka bertindak dalam situasi sesuai dengan motto Aflatoun yaitu Jelajahi, Pikirkan, Selidiki dan Bertindak. Metode pembelajaran meliputi bercerita, lagu , drama dan tari, permainan, klub tabungan, perusahaan keuangan dan kegiatan bermasyarakat. Kurikulum Program Aflatoun disempurnakan selama 17 tahun setelah dilakukan penelitian di India, diikuti oleh 10 proyek percontohan di seluruh dunia. Dan program ini telah diadaptasi sesuai dengan kebutuhan anak-anak di berbagai daerah dan dari berbagai usia, kemudian diajarkan baik di kelas maupun di luar sekolah. Mitra Aflatoun telah menerjemahkan kurikulum ke dalam lebih dari 30 bahasa dan telah dikontekstualisasikan dan diajarkan lebih dari 60 Negara. ${ }^{21}$

Aflatoun yang memberikan Pendidikan Finansial dan Sosial secara seimbang pada anak muda di seluruh dunia. Terbentuk dari empat sub program, yaitu Aflatot, Aflatoun, Aflateen dan afla akademi, program ini menjangkau anak-anak yang berusia antara 3 sampai 18 tahun keatas. Pendidikan Finansial dan Sosial bertujuan untuk membantu anak muda berfikir secara kritis, belajar tentang hak dan tanggung jawab, dan mendapatkan pengetahuan finansial dan kecakapan yang akan membuat mereka bisa meraih impian mereka. Ia juga membantu mereka merefleksikan dan membuat bermakna transisi kehidupan yang mereka lalui. Pendidikan sosial mengajarkan mereka percaya pada diri mereka sendiri dan menjadi warga yang bertangung jawab dengan memahami dan terlibat dalam isu-isu sosial yang berpengaruh pada mereka. Pendidikan Finansial mengajarkan mereka kecakapan yang penting tentang tabungan, membelanjakan dengan bijak berdasarkan kebutuhan, anggaran serta perencanaan keuangan untu masa depan, serta terlibat dalam usaha finansial dan sosial. ${ }^{22}$

21 http://www.Aflatoun.org/programme/programme-selected/curriculum, diakses hari Jumat 25 Oktober 2013 pukul 18.30 WIB

${ }^{22}$ Suryadi, Juknis, h.1. 


\section{Kurikulum Program Aflatoun}

Metodologi pengajaran Aflatoun mendorong "learning by doing". Kurikulum memberikan pelajaran terstruktur yang digunakan pada game , seni dan teater memastikan bahwa belajar adalah menyenangkan serta efektif. Guru dilatih dalam metodologi pengajaran progresif yang memastikan anak-anak berpartisipasi aktif dalam suasana yang bebas dari ancaman kekerasan dan penuh tawa dan pembelajaran. Aflatoun memimpin anak melalui perjalanan belajar mereka dan membantu untuk menciptakan ikatan emosional antara anak dan materi program .

Sedangkan kurikulum Aflatoun terbagi menjadi tiga sub bagian, pertama kurikulum Aflatot yaitu kurikulum pra sekolah. Dan kedua kurikulum Aflatoun Berbasis Sekolah ( 6-14 tahun ) Kurikulum Aflatoun ini didasarkan pada lima elemen inti .

a. Pemahaman pribadi dan eksplorasi

b. Memahami dan mengeksplorasi hak dan tanggung jawab

c. Konsep menabung dan membelanjakan uang

d. Pelajari bagaimana merencanakan dan anggaran, keterampilan yang membuat mereka menyadari bahwa mereka memiliki pilihan dan kontrol atas bagaimana mereka dapat menggunakan sumber daya mereka .

e. Anak-anak menunjukkan dan mempraktekkan pembelajaran mereka melalui mikro - usaha sosial dan keuangan di mana mereka berkolaborasi sebagai tim dan menemukan bagaimana mereka dapat membuat masyarakat setempat lingkungan yang lebih aman, sehat dan adil. $^{23}$

Yang ketiga adalah kurikulum Aflateen yaitu bagi anak muda usia 15

- 18 tahun atau lebih. Materi Aflatoun bisa diimplementasikan dengan cara;

a. Diintegrasikan dengan pelajaran lain

b. Sebagai kegiatan ekstrakurikuler

c. Sebagai Muatan lokal

d. Atau diimplementasikan sebagai materi tambahan untuk peningkatan life skill dalam pendidikan sosial dan finansial.

i. Kurikulum Aflatoun terdiri dari 8 buku kerja.

e. Buku Kerja Satu : Unik dan berbeda, Saling menghormati, Konsep menabung.

${ }^{23}$ http://www.Aflatoun.net/curriculum, diakses hari Selasa, 29 Oktober 2013 pukul 19.30 WIB 
f. Buku Kerja Dua : Kemandirian anak dari; keluarga, tentangga \& masyarakat, Uang sebagai alat untuk memenuhi kebutuhan bukan untuk memenuhi keinginan.

g. Buku Kerja Tiga : Explorasi diri dengan memahami perasaan, etika keuangan, \& transparansi.

h. Buku Kerja Empat : Sikap yang bertanggung jawab \& Pengembangan sikap cinta dan bangga nasionalisme, kegiatan bersama \& kerja tim, keterampilan organisatoris.

i. Buku Kerja Lima : Kebutuhan, Hak dan tanggung jawab, pendapatan, Menabung \& membelanjakan, Demokrasi \& Kepemimpinan, Pemenuhan kebutuhan dan kesejahteraan.

j. Buku Kerja Enam : Marjinalisasi \& Exclusi, Usaha anak, Perencanaan \& Penganggaran, Bank Formal, Ekplorasi Kemiskinan

k. Buku Kerja Tujuh : Mitos dan Stereotype, Latar belakang tujuan finansial, Kegiatan interprise, explorasi hubungan antara pendapatan, pembelanjaan, tabungan, dan investasi.

1. Buku Kerja Delapan : Refleksi diri, Biases and prejudices (berpikir berbeda), stereotype gender, Pengembangan kemampuan finansial. ${ }^{24}$

\section{Tujuan Implementasi Program Aflatoun}

Anak-anak memiliki potensi besar. Mereka memiliki penilaian, bertindak atas sendiri, memimpin orang lain, atau bekerja sebagai bagian dari tim. Ini adalah keterampilan yang sering berkembang atau tidak diketahui, meskipun dampak yang mendalam bahwa kemampuan tersebut terhadap masa depan mereka dan dunia

Aflatoun berusaha untuk memanfaatkan masa awal kehidupan seorang anak dan memberi mereka pengalaman pendidikan yang membuat mereka dengan asosiasi positif dengan uang dan perubahan sosial. Anak adalah waktu yang berharga, dimana pembangunan eksplorasi, pembelajaran dan karakter adalah kunci. Dengan mengajarkan keterampilan sosial dan keuangan dasar, dan memberikan anak-anak dengan pengalaman praktis, Aflatoun berharap bahwa mereka akan percaya diri dan mampu untuk membuat perbedaan dalam kehidupan mereka dan kehidupan orangorang di sekitar mereka. ${ }^{25}$

\footnotetext{
${ }^{24}$ Sekretariat Aflatoun Indonesia, Aflatoun Teacher's Manual, terj. Lapis (Program for Islamic school supported by Australian Governmen), Manual Guru Aflatoun (Jakarta: Lekdis Nusantara, Lembaga Kajian Pendidikan, Keislaman dan sosial Nusantara, 2008), h.iii.

25 http://www.Aflatoun.org/story/story-selected/dream-and-goal diakses hari kamis 22 Novemer 2013 pukul 19.40 WIb
} 
Implementasi Program Aflatoun di Pesantren bertujuan untuk membangun dan membentuk sikap sosial yang lebih baik antar sesama, mengingat kehidupan para santri yang hitrogen dan membutuhkan pembelajaran hidup yang mandiri dengan keterampilan sosial dan keuangan. Sedangkan sikap sosial yang diajarkan di Pesantren menurut K. H. R. Zainuddin Fananie terbagi menjadi dua. Yang pertama adalah mengajarkan segala kewajiban supaya hidup sebagai manusia yang dapat berkomunikasi dan bergaul dengan sesama dengan baik. Dan yang kedua adalah Akhlaq dan etika/kesopanan. ${ }^{26}$

\section{Hakikat Pendidikan Karakter}

Kata "character" berasal dari bahasa Yunani charassein, yang berarti to engrave (melukis, menggambar), seperti orang yang melukis kertas, memahat batu atau metal. Berakar dari pengertian seperti itu,karakter kemudian diartikan sebagai tanda atau ciri yang khusus, dan karenanya melahirkan suatu pandangan bahwa karakter adalah pola prilaku yang bersifat individual, keadaan moral seseorang. Setelah melewati tahap anakanak, seseorang memiliki karakter, cara yang dapat diramalkan bahwa karakter seseorang berkaitan dengan prilaku yang berada di sekitarnya.

Makna dari pengertian pendidikan karakter yaitu merupakan berbagai usaha yang dilakukan oleh para personil sekolah, bahkan yang dilakukan bersama-sama dengan orang tua dan anggota masyarakat, untuk membantu anak-anak dan remaja agar menjadi atau memili sifat peduli, berpendirian, dan bertanggung jawab. ${ }^{27}$

Mengacu kepada kamus besar bahasa Indonesia, edisi kedua, Depdikbud Balai Pustaka 1996, kata karater ini memiliki beberapa sinonim, antara lain : sifat-sifat kejiwaan, akhlaq atau budi pekerti yang membedakan seseorang dari yang lain; tabiat, watak. ${ }^{28}$

Dan mengacu kepada Oxford Advanced Leaner's Dictionary of current English, Oxford University Press, London, 1981 oleh AS. Hornby, Kata karakter adalah mental or moral nature; mental or moral qualities that makes one person, race, etc different from other (adalah keadaan moral atau mental seseorang masyarakat bangsa dan sebagainya; kualitas mental atau moral membentuk seseorang, bangsa, dan sebagainya berbeda dari yang lain) ${ }^{29}$.

${ }^{26}$ Zainuddin Fananie, Pedoman Pendidikan Modern (Solo : Tinda Medina, 2011), h.24.

27 Daryanto \& Suryatri Darmiatun, Implementasi Pendidikan Karakter di Sekolah (Yogyakarta: Gava Media, 2013). h. 64.

${ }^{28}$ Suparman Sumahami Jaya dkk, Pendidikan Karakter Mandiri dan Kewiraswataan (Bandung : Angkasa, 2002). h. 29.

${ }^{29}$ Ibid, h. 30.

Jurnal Pendidikan Agama Islam

Volume 3 Nomor 2 November 2015

ISSN: 2089-1946

Hal. 430 - 449 
Apakah pendidikan karakter itu sama dengan pendidikan moral? Jika sama, kenapa mesti disebut pendidikan karakter dan tidak disebut pendidikan moral saja?. Menurut T Ramli, pendidikan karakter itu memiliki nilai dan esensi yang sama dengan moral atau pendidikan akhlak.Tujuannya adalah membentuk pribadi anak, supaya menjadi pribadi yang baik, jika di masyarakat menjadi warga yang baik. ${ }^{30}$ Oleh karena itu hakikat karakter dalam dalam konteks pendidikan di Indonesia adalah pendidikan nilai, yakni pendidikan nilai luhur yang bersumber dari budaya bangsa Indonesia sendiri, dalam rangka membina kepribadian generasi muda.

Di Indonesia, pembangunan karakter adalah upaya perwujudan amanat Pancasila dan Pembukaan UUD 1945 yang dilatarbelakangi oleh realita permasalahan kebangsaan yang berkembang saat ini, di antaranya adalah bergesernya nilai etika dalam kehidupan berbangsa dan bernegara dan melemahnya kemandirian bangsa. ${ }^{31}$

Semangat itu secara implisit ditegaskan dalam Rencana Pembangunan Jangka Panjang Nasional (RPJPN) tahun 2005-2015 di mana pendidikan karakter ditempatkan sebagai landasan untuk mewujudkan visi pembangunan Nasional yaitu "mewujudkan masyarakat berakhlak mulia, bermoral, beretika, berbudaya, dan beradap berdasarkan falsafah pancasila"32

Yang dimaksud dengan Pendidikan karakter adalah pendidikan yang menanamkan dan mengembangkan karakter-karakter luhur kepada anak didik, sehingga mereka memiliki karakter luhur itu, menerapkan dan mempraktikkan dalam kehidupannya baik di keluarga, masyarakat, dan negara. ${ }^{33}$

Sementara itu, Berkowitz dan Bier berpendapat bahwa pendidikan karakter merupakan penciptaan lingkungan sekolah yang membantu peserta didik dalam perkembangan etika, tanggung jawab melalui model dan pengajaran karakter yang baik melalui nilai-nilai universal. ${ }^{34}$

Berdasarkan pengertian di atas, pendidikan karakter adalah sistem penanaman nilai-nilai karakter kepada peserta didik sehingga mereka menerapkan dalam kehidupannya baik di keluarga, sekolah, masyarakat,

\footnotetext{
${ }^{30}$ Agus Wibowo, Pendidikan Karakter... h. 34.

${ }^{31}$ Daryanto \& Suryatri Darmiatun, Implementasi Pendidikan Karakter. h. 41.

32 Ibid, h. 41

${ }^{33}$ Agus Wibowo, Pendidikan Karakter... h. 36.

${ }^{34}$ Berkowitz, M.W, and Bier, Melinda, C, What Works In Character Education: A Researchdriven guide for educators, (Washington, DC Univesity of Missouri-St Louis. 2005), h. 7
} 
dan negara sehingga dapat memberikan kontribusi yang positif kepada lingkungannya.

Maka pendidikan karakter merupakan berbagai usaha yang dilakukan oleh para para personil sekolah, bahkn dilakukan bersama-sama dengan orang tua dan anggota masyarakat, untuk membantu anak-anak dan remaja agar menjadi atau memiliki sifat peduli, berpendirian dan bertanggung jawab.

Sehingga pendidikan karakter sangat perlu untuk diterapkan di sekolah, menurut Lickona ada tujuh alasan mengapa pendidikan karakter ini perlu disampaikan :

a. Merupakan cara terbaik untuk menjamin anak-anak (siswa) memiliki kepribadian yang baik dalam kehidupannya;

b. Merupakan cara untuk meningkatkan hasil akademik;

c. Sebagaian siswa tidak dapat membentuk karakter yang kuat bagi dirinya di tempat lain;

d. Mempersiapkan siswa untuk menghormati pihak atau orang lain dan dapat hidup dalam masyarakat yang beragam;

e. Berangkat dari akar masalah yang berkaitan dengan problem moral sosial, seperti ketidak sopanan, ketidak jujuran, kekerasan, pelanggaran kegiatan seksual, dan etos kerja (belajar) yang rendah;

f. Merupakan persiapan terbaik untuk menyongsong prilaku di tempat kerja;

g. Mengajarkan nilai-nilai budaya merupakan bagian dari kerja peradaban. ${ }^{35}$

\section{Tujuan dan Sasaran Pendidikan Karakter}

Pendidikan karakter pada intinya bertujuan untuk membentuk bangsa yang tangguh, kompetitif, berakhlak mulia, bermoral, bertoleran, bergotong royong, berjiwa patriotik, berkembang dinamis, berorientasi ilmu pengetahuan dan teknoligi yang semuanya dijiwai oleh iman dan takwa kepada Tuhan yang maha esa berdasarkan pancasila.

Pendidikan karakter bertujuan untuk meningkatkan mutu penyelenggaraan dan hasil pendidikan di sekolah yang mengarah kepada pencapaian pembentukan karakter atau akhlak mulia peserta didik secara utuh, terpadu dan seimbang. Sesuai standar kompetisi lulusan. Melalui pendidikan karakter diharapkan peserta didik SMP/MTs mampu secara mandiri meningkatkan dan menggunakan pengetahuannya, mengkaji dan

35 Daryanto \& Suryatri Darmiatun, Implementasi Pendidikan... h.64. 
menginternalisasi serta mempersolisasi nilai-nilai karakter dan akhlak mulia sehingga terwujud dalam prilaku sehari-hari. ${ }^{36}$

Sementara tujuan pendidikan karakter yang diharapkan Kementerian Pendidikan Nasional ${ }^{37}$ adalah:

a. Mengembangkan potensi kalbu/nurani/afektif peserta didik sebagai manusia dan warganegara yang memiliki nilai-nilai budaya dan karakter bangsa.

b. Mengembangkan kebiasaan dan perilaku peserta didik yang terpuji dan sejalan dengan nilai-nilai universal dan tradisi budaya bangsa yang religius.

c. Menanamkan jiwa kepemimpinan dan tanggung jawab peserta didik sebagai generasi penerus bangsa.

d. Mengembangkan kemampuan peserta didik menjadi manusia yang mandiri, kreatif, berwawasan kebangsaan; dan

e. mengembangkan lingkungan kehidupan sekolah sebagai lingkungan belajar yang aman, jujur, penuh kreativitas dan persahabatan, serta dengan rasa kebangsaan yang tinggi dan penuh kekuatan (dignity).

Pendidikan Karakter pada tingkat institusi mengarah pada pembentukan budaya sekolah, yaitu nilai-nilai yang melandasi prilaku, tradisi, kebiasaan keseharian, dan simbol-simbol yang dipraktekkan dalam semua warga sekolah dan masyarakat sekitar sekolah. Budaya sekolah merupakan ciri khas, karakter atau watak, dan citra sekolah tersebut di mata masyarakat luas.

Sementara Sasaran Pedidikan Karakter adalah seluruh sekolah Menengah Pertama (SMP) di Indonesia negeri maupun swasta. Semua warga sekolah, meliputi para peserta didik, guru, karyawan administrasi,dan pimpinan sekolah menjadi sasaran program ini. Sekolahsekolah yang selama ini telah berhasil melaksanakan pendidikan karakter dengan baik dijadikan sebagai contoh untuk disebarluaskan ke sekolah lainnya. Melalui program ini diharapkan lulusan SMP dan MTs memiliki keimanan dan ketakwaan kepada Tuhan Yang Maha Esa, berakhlaq mulia, kompetensi akademik yang utuh dan terpadu, sekaligus memiliki kepribadian yang baik sesuai norma-norma dan budaya Indonesia. Pada tataran yang lebih luas pendidikan karakter nantinya akan menjadi budaya sekolah. 38

${ }^{36}$ Ibid. h. 45.

37 Kementerian Pendidikan Nasional, Desain Induk Pendidikan Karakter Kementerian Pendidikan Nasional (Jakarta, 2010a). h. 9

38 Daryanto \& Suryatri Darmiatun, Implementasi Pendidikan... h. 46. 


\section{Nilai-nilai Pendidikan Karakter}

Menurut Kesuma karakter berasal dari nilai tentang sesuatu. Suatu karakter melekat dengan nilai dari perilaku seseorang. Karenanya tidak ada perilaku anak yang tidak bebas dari nilai. Dalam kehidupan manusia, begitu banyak nilai yang ada di dunia ini, sejak dahulu sampai sekarang. ${ }^{39}$

Nilai-nilai pendidikan karakter yang dikembangkan Kementerian Pendidikan ada delapan belas karakter. Nilai-nilai tersebut bersumber dari agama, pancasila, budaya, dan tujuan pendidikan nasional. Adapun delapan belas nilai tersebut yaitu: religius, jujur, toleransi, disiplin, kerja keras, kreatif, mandiri, demokratis, rasa ingin tahu, semangat kebangsaan, cinta tanah air, menghargai prestasi, bersahabat/komunikatif, cinta damai, gemar membaca, peduli lingkungan, peduli sosial, dan tanggung jawab. ${ }^{40}$

Meskipun telah terdapat 18 nilai pembentuk karakter bangsa, namun satuan pendidikan dapat menentukan prioritas pengembangannya dengan cara melanjutkan nilai prakondisi yang diperkuat dengan beberapa nilai yang diprioritaskan dari 18 nilai di atas.

Ke 18 nilai pendidikan karakter tersebut menurut Kemendiknas, jika diringkas diantaranya sebagai berikut :

\section{Tabel 1}

Nilai dan Deskripsi Pendidikan Karakter ${ }^{41}$

\begin{tabular}{|c|c|c|}
\hline NO & Nilai & Deskripsi \\
\hline 1 & Religius & $\begin{array}{c}\text { Sikap dan prilaku yang patuh dalam } \\
\text { melaksanakan ajaran agama yang } \\
\text { dianutnya, toleran dalam pelaksanaan } \\
\text { ibadah agama lain, dan hidup rukun } \\
\text { dengan pemeluk agama lain }\end{array}$ \\
\hline 2 & & Prilaku yang didasarkan pada upaya \\
& Jujur & menjadikan dirinya sebagai orang yang \\
& & selalu dapat dipercaya dalam perkataan, \\
\hline
\end{tabular}

39 Kesuma, dkk, Pendidikan Karakter: Kajian Teori dan Praktik di Sekolah, (Bandung: PT. Remaja Rosdakarya, 2011). h.11.

40 Pusat Kurikulum Balitbang Kemdiknas, Pengembangan dan Pendidikan Budaya \& Karakter Bangsa: Pedoman Sekolah, (Jakarta: Puskur Balitbang Kemdiknas, 2009). h. 9-10.

41 Kementrian Pendidikan Nasional, Pengembangan Budaya dan karakter bangsa. Bahan pelatihan penguatan metodelogi Pembelajaran berdasarkan nilai-nilai budaya untuk membentuk daya saing dan karakter bangsa. (Jakarta: Kemendiknas, 2010) h. 9-10. 


\begin{tabular}{|c|c|c|}
\hline & & tindakan dan pekerjaan. \\
\hline 3 & Toleransi & $\begin{array}{l}\text { Sikap dan tindakan yang menghargai } \\
\text { perbedaan agama, suku, etnis, pendapat, } \\
\text { sikap, dan tindakan orang lain yang } \\
\text { beberapa dari dirinya. }\end{array}$ \\
\hline 4 & Disiplin & $\begin{array}{l}\text { Tindakan yang menunjukkan prilaku } \\
\text { tertib dan patuh pada berbagai } \\
\text { ketentuan dan peraturan }\end{array}$ \\
\hline 5 & Kerja Keras & $\begin{array}{c}\text { Prilaku yang menunjukkan upaya } \\
\text { sungguh-sungguh dalam mengatasi } \\
\text { berbagai hambatan belajar, tugas dan } \\
\text { menyelesaikan tugas dengan sebaik- } \\
\text { baiknya }\end{array}$ \\
\hline 6 & Kreatif & $\begin{array}{l}\text { Berpikir dan melakukan sesuatu untuk } \\
\text { menghasilkan cara atau hasil baru dari } \\
\text { sesuatu yang telah dimiliki }\end{array}$ \\
\hline 7 & Mandiri & $\begin{array}{l}\text { Sikap dan prilaku yang tidak mudah } \\
\text { tergantung pada orang lain dalam } \\
\text { menyelesaikan tugas-tugas }\end{array}$ \\
\hline 8 & Demokratis & $\begin{array}{l}\text { Cara berpikir, bersikap dan bertindak } \\
\text { yang menilai sama hak dan kewajiban } \\
\text { dirinya dan orang lain }\end{array}$ \\
\hline 9 & Rasa ingin tau & $\begin{array}{c}\text { Sikap dan prilaku yang selalu berupaya } \\
\text { untuk mengetahui lebih mendalam dan } \\
\text { meluas dari sesuatu yang dipelajarinya, } \\
\text { dilihat, dan didengar }\end{array}$ \\
\hline 10 & Semangat kebangsaan & $\begin{array}{c}\text { Cara berpikir, bertindak, dan } \\
\text { berwawasan yang menempatkan } \\
\text { kepentingan bangsa dan Negara di atas } \\
\text { kepentingan diri dan kelompoknya }\end{array}$ \\
\hline 11 & Cinta tanah Air & $\begin{array}{l}\text { Cara berpikir, bersikap, dan berbuat } \\
\text { yang menunjukkan kesetiaan, } \\
\text { kepedulian, dan penghargaan yang } \\
\text { tinggi terhadap bangsa, lingkungan fisik, } \\
\text { sosial, budaya, ekonomi dan politik } \\
\text { bangsa }\end{array}$ \\
\hline 12 & Menghargai Prestasi & $\begin{array}{l}\text { Sikap dan tindakan yang mendorong } \\
\text { dirinya untuk menghasilkan sesuatu }\end{array}$ \\
\hline
\end{tabular}




\begin{tabular}{|c|c|c|}
\hline & & $\begin{array}{c}\text { yang berguna bagi masyarakat, dan } \\
\text { mengakui, serta menghormati } \\
\text { keberhasilan orang lain }\end{array}$ \\
\hline 13 & Bersahabat/komunikatif & $\begin{array}{c}\text { Tindakan yang memperlihatkan rasa } \\
\text { senang berbicara, bergaul, dan } \\
\text { bekerjasama dengan orang lain }\end{array}$ \\
\hline 14 & Cinta Damai & $\begin{array}{c}\text { Sikap, perkataan dan tindakan yang } \\
\text { menyebabkan orang lain merasa senang } \\
\text { dan aman atas kehadiran dirinya. }\end{array}$ \\
\hline 15 & Gemar membaca & $\begin{array}{l}\text { Kebiasaan menyediakan waktu untuk } \\
\text { membaca berbagai bacaan yang } \\
\text { memberikan kebajikan bagi dirinya. }\end{array}$ \\
\hline 16 & Peduli lingkungan & $\begin{array}{c}\text { Sikap dan tindakan yang selalu } \\
\text { berupaya mencegah kerusakan pada } \\
\text { lingkungan alam di sekitarnya, dan } \\
\text { mengembangkan upaya-upaya untuk } \\
\text { memperbaiki kerusakan alam yang } \\
\text { sudah terjadi. }\end{array}$ \\
\hline 17 & Peduli sosial & $\begin{array}{l}\text { Sikap dan tindakan yang selalu ingin } \\
\text { member bantuan pada orang lain dan } \\
\text { masyarakat yang membutuhkan }\end{array}$ \\
\hline 18 & Tanggung jawab & $\begin{array}{c}\text { Sikap dan prilaku seseorang untuk } \\
\text { melaksanakan tugas dan kewajibanya, } \\
\text { yang seharusnya dia lakukan, terhadap } \\
\text { diri sendiri, masyarakat, lingkunagan } \\
\text { (alam, sosial dan budaya), negara dan } \\
\text { Tuhan Yang Maha Esa. }\end{array}$ \\
\hline
\end{tabular}

Sumber : Kementrian Pendidikan Nasional (2010)

Ke 18 nilai karakter di atas bersumber dari nilai-nilai berikut ini:

a. Agama: nilai-nilai pendidikan budaya dan karakter bangsa harus didasarkan pada nilai-nilai dan aqidah yang bersal dari agama.

b. Pancasila: Pendidikaan budaya dan karakter bangsa bertujuan mempersiapkan peserta didik menjadi warga Negara yang lebih baik, yaitu warga Negara yang memiliki kemapuan, kemauan, dan menerapkan nilai-nilai pancasila dalam kehidupannya sebagai warga Negara.

c. Budaya: tidak ada manusia yang hidup bermasyarakat yang tidak didasari oleh nilai-nilai budaya yang diakui masyarakat tersebut. Nilai- 
nilai budaya tersebut dijadikan dasar dalam member makna terhadap suatu konsep dan arti dalam komunikasi antar anggota masyarakat tersebut.

d. Tujuan Pendidikan Nasional: Tujuan pendidikan nasional adalah sumber yang paling operasioanal dalam pengembangan pendidikan budaya dan karakter bangsa dibandingkan ketiga sumber yang disebutkan di atas.

e. Undang-undang Republik Indonesia (UURI) no 17 tahun 2007 tentang RPJPN: tangguh, kompetitif, berakhlak mulia, bermoral, bertoleran, bergotong royong, patriotik, dinamis, berbudaya, dan berorientasi iptek (ilmu pengetahuan dan teknologi) berdasarkan pancasila dan dijiwai oleh iman dan takwa kepada Tuhan Yang Maha Esa. ${ }^{42}$

Dalam implementasinya jumlah dan jenis karakter yang dipilih tentu akan dapat berbeda antara satu daerah atau sekolah yang satu dengan yang lain. Hal itu tergantung pada kepentingan dan kondisi satuan pendidikan masing-masing. Di antara berbagai nilai yang dikembangkan dalam pelaksanaanya dapat dimulai dari nilai yang esensial, sederhana dan mudah dilaksanakan sesuai dengan kondisi masing-masing sekolah, wilayah, yakni bersih, rapih, nyaman, disiplin, sopan dan santun. ${ }^{43}$

\section{Metode dan tujuan Penelitian}

Penelitian ini bertujuan; (1) Untuk mendeskripsikan Proses Implementasi Program Aflatoun dalam Pendidikan Karakter Siswa di lembaga penyelenggara di Madura; (2) Untuk mendeskripsikan muatan kurikulum Aflatoun dalam Pendidikan Karakter Siswa di lembaga penyelenggara di Madura; (3) Untuk mendeskripsikan tujuan Implementasi Program Aflatoun di di lembaga penyelenggara di Madura; (4) Untuk mendeskripsikan Target Implementasi Program Aflatoun di di lembaga penyelenggara di Madura; (5) Untuk mendeskripsikan Karakter apa sajakah yang menjadi target/sasaran dalam program Implementasi Program Aflatoun di di lembaga penyelenggara di Madura; (6) Untuk mendeskripsikan penilaian keberhasilan implementasi Program Aflatoun dalam Pendidikan Karakter siswa di lembaga penyelenggara di Madura. Pendekatan yang digunakan dalam penelitian ini adalah pendekatan kualitatif deskriptif, di mana data dalam penelitian ini dikumpulkan dengan observasi, wawancara, dan analisis dokumen.

42 Daryanto \& Suryatri Darmiatun, Implementasi Pendidikan... h.69.

${ }^{43}$ Ibid... h. 48. 


\section{Hasil Penelitian}

Proses implementasi Program Aflatoun dalam pendidikan karakter disampaikan dalam kegiatan ekstrakurikuler. Program tersebut juga dapat dilakukan dengan banyak cara, bisa sebagai kurikulum tambahan yang diintegrasikan dengan mata pelajaran lain, namun juga bisa disampaikan dalam kegiataan ekstrakurikuler. Kepala sekolah juga menegaskan bahwa program Aflatoun merupakan kegiatan yang sangat penting untuk diikuti oleh para siswa. Sebab program tersebut mengajarkan nilai-nilai yang baik terutama di dalam membangun pendidikan karakter dalam diri siswa.

Hal itu juga disampaikan oleh salah satu guru/tutor Aflatoun, bahwa menurutnya program Aflatoun disampaikan dalam bentuk ekstrakurikuler dengan membentuk kelompok Aflatoun yang terdiri dari kelompok Aflatoun zona putra dan kelompok Aflatoun zona putri. Masing-masing kelompok berbeda organisasi dan kepengurusan, artinya zona putra dan putri bisa jadi akan berbeda cara atau teknik penyampaiannya walaupun materi dan kurikulumnya relatif sama.

Temuan tersebut telah sesuai dengan metodelogi impelementasi aflatoun, yaitu bahwa program ini selain dapat diselenggarakan di kelas dalam kegiatan belajar mengajar, dengan diintegrasikan dengan materi pelajaran di kelas, program Aflatoun ini juga dapat diselenggarakan dalam kegiatan ekstrakurikuler ${ }^{4}$

Pelaksanaan program ini disampaikan dengan pendekatan dan metode pembelajaran fun learning dan students oriented metode ini mampu meningkatkan minat siswa untuk mengikuti kegiatan hingga selesai.

Metode pembelajaran fun learning dan students oriented yang diterapkan pada program Aflatoun ini sesuai dengan metode yang dikembangkan oleh Kementrian Pendidikan dan Kebudayaan Nasional dalam pengembangan kurikulum 2013 yaitu proses pembelajaran yang mengedepankan pengalaman personal melalui observasi (menyimak, melihat, membaca dan mendengar) yang berpusat kepada peserta didik (student's centered and active learning) dengan sifat pembelajaran yang kontekstual. ${ }^{45}$ Dengan beberapa metode seperti metode bercerita, problem solving, reflective thinking/critical thinking, group dynamic, community building, responsibility building, picnic, camping study, kerja individu dan kelompok. ${ }^{46}$

\footnotetext{
${ }^{44}$ Sekretariat Aflatoun Indonesia, Aflatoun Teacher's Manual... h.iii.

45 Pengembangan kurikulum 2013, bahan uji publik kemendikbud

${ }^{46}$ Maridiyanto, Psikologi pendidikan : Landasan untuk pengembangan strategi pembelajaran (Medan: Perdana Publishing, 2013). h. 122.
} 
Implementasi program Aflatoun ini juga menggunakan pendekatan pembelajaran yang sesuai dengan acuan Pendidikan Nasional yang dapat digunakanuntuk pendidikan karakter seperti pendekatan belajar aktif dan ICARE (introduction,connection, application, reflection, extension). ${ }^{47}$

Hal ini juga telah sesuai dengan salah satu prinsip Kemendiknas dalam mengembangkan pendidikan karakter. Bahwa salah satunya adalah proses pendidikan dilakukan dengan penekanan agar peserta didik secara aktif dan menyenangkan. Pendidikan karakter dilakukan oleh peserta didik bukan oleh guru, guru menerapkan prinsip "tutwuri handayani". ${ }^{4}$

Sementara itu dalam proses implementasi program Aflatoun dalam pendidikan karakter di beberapa sekolah di Madura telah mengacu kepada nilainilai pendidikan karakter Nasional. Nilai pendidikan yang dikembangkan oleh Kementerian Pendidikan ada delapan belas karakter. Nilai-nilai tersebut bersumber dari agama, pancasila, budaya, dan tujuan pendidikan nasional. Adapun delapan belas nilai tersebut yaitu: religius, jujur, toleransi, disiplin, kerja keras, kreatif, mandiri, demokratis, rasa ingin tahu, semangat kebangsaan, cinta tanah air, menghargai prestasi, bersahabat/komunikatif, cinta damai, gemar membaca, peduli lingkungan, peduli sosial, dan tanggung jawab.

Langkah-langkah implementasinya mengacu kepada peraturan Menteri Pendidikan Nasional nomor 41 tahun 2007 tentang standar proses. Yang mana disebutkan bahwa langkah-langkah tersebut terdiri dari pendahuluan, isi dan penutup.

Pada bagian pendahuluan guru Aflatoun menyampaikan beberapa materi yang telah diajarkan sebelumnya dan menjelaskan tujuan, kompetensi dari pembelajaran termasuk juga nilai karakter yang ingin dicapai. Kemudian pada bagian isi, guru Aflatoun menyampaikan materi dengan metode kelompok yang menyenangkan. Pada bagian ini guru Aflatoun menggunakan 8 buku kerja Aflatoun dengan petunjuk pembelajaran yang sudah cukup komprehensif. Pada bagian akhir/penutup, guru Aflatoun mengakhiri pembelajaran dengan menekankan nilai karakter yang menjadi indikator/kompetensi dari judul/materi yang ada pada buku kerja Aflatoun yang telah dipilih sesuai dengan kebutuhan.

Langkah-langkah ini sudah sesuai dengan metode yang ditawarkan oleh Aflatoun yaitu yang terdapat dalam buku manual guru Aflatoun dimana seorang guru Aflatoun bisa memilih materi pembelajaran yang terdapat dalam buku kerja Aflatoun dengan menyesuaikan dengan kebutuhan anak.

\footnotetext{
${ }^{47}$ Daryanto \& Suryatri Darmiatun, Implementasi Pendidikan... h. 75.

${ }^{48}$ Agus wibowo, Pendidikan Karakter....h. 75.
} 
Muatan kurikulum Program Aflatoun yang digunakan mengacu pada 8 buku kerja Aflatoun.

1. Buku Kerja Satu (6-7 tahun) : Unik dan berbeda, Saling menghormati, Konsep menabung.

2. Buku Kerja Dua (7-8 tahun): Kemandirian anak dari; keluarga, tentangga \& masyarakat, Uang sebagai alat untuk memenuhi kebutuhan bukan untuk memenuhi keinginan.

3. Buku Kerja Tiga (8-9 tahun): Explorasi diri dengan memahami perasaan, etika keuangan, \& transparansi.

4. Buku Kerja Empat (9-10 tahun) : Sikap yang bertanggung jawab \& Pengembangan sikap cinta dan bangga nasionalisme, kegiatan bersama \& kerja tim, keterampilan organisatoris.

5. Buku Kerja Lima (10-11 tahun) : Kebutuhan, Hak dan tanggung jawab, pendapatan, Menabung \& membelanjakan, Demokrasi \& Kepemimpinan, Pemenuhan kebutuhan dan kesejahteraan.

6. Buku Kerja Enam (11-12 tahun) : Marjinalisasi \& Exclusi, Usaha anak, Perencanaan \& Penganggaran, Bank Formal, Ekplorasi Kemiskinan

7. Buku Kerja Tujuh (12-13 tahun) : Mitos dan Stereotype, Latar belakang tujuan finansial, Kegiatan interprise, explorasi hubungan antara pendapatan, pembelanjaan, tabungan, dan investasi.

8. Buku Kerja Delapan (13-14 tahun) : Refleksi diri, Biases and prejudices (berpikir berbeda), stereotype gender, Pengembangan kemampuan finansial.

Namun, dalam implementasinya, pembelajaran 8 buku kerja Aflatoun ini tidak dapat seluruhnya diajarkan, hal ini disebabkan waktu dan kesempatan yang tidak mencukupi. Namun guru Aflatoun telah melakukan pemilihan materi yang dapat mewakili dan membantu ketercapaian tujuan implementasi program Aflatoun dalam pendidikan karakter siswa.

Dalam kaitannya dengan muatan kurikulum berkarakter Nasional, maka peraturan Pemerintah RI no 33 tahun 2013 pasal 77j ayat (3) menyebutkan bahwa Struktur Kurikulum pada tingkat SMP/MTs/SMPLB atau bentuk lain yang sederajat terdiri atas muatan : a. Pendidikan agama; b. Pendidikan kewarganegaraan; c. Bahasa; d. Matematika; e. Ilmu Pengetahuan Alam; f. Ilmu Pengetahuan Sosial; g. Seni dan budaya; h. Pendidikan jasmani dan olahraga; i. Ketrampilan/kejuruan; dan j. Muatan lokal.49

Menurut kemendikanas, kurikulum pendidikan karakter tidak dimasukkan sebagai pokok bahasan, tetapi terintegrasi ke dalam mata pelajaran, pengembangan diri dan budaya sekolah. Oleh karena itu, guru dan pemangku kebijakan pendidikan di sekolah perlu menginternalisasikan nilai-nilai yang

${ }^{49}$ Peraturan pemerintah RI No 33 tahun 2013 pasal 77j ayat (3)

Jurnal Pendidikan Agama Islam

Volume 3 Nomor 2 November 2015

ISSN: 2089-1946

Hal. 440 - 449 
dikembangkan dalam pendidikan karakter ke dalam kurikulum tingkat satuan pendidikan (KTSP), Silabus, dan rencana program pembelajaran (RPP). 50

Prinsip Kemendiknas dalam pengembangan pendidikan karakter yaitu; 1), berkelanjutan, artinya bahwa pendidikan karakter merupakan proses panjang, dimulai dari awal peserta didik masuk sampai dari suatu satuan pendidian. 2), Melalui semua mata pelajaran, pengembangan diri dan budaya sekolah. Artinya proses nilai-nilai karkter dilakukan melalui setiap mata pelajaran, dan dalam setiap kegiatan ekstra kurikuler. ${ }^{51}$ Sebagaimana gambar skema di bawah ini:

\section{Gambar 2 Skema Pengembangan Nilai-nilai Pendidikan Karakter Bangsa}

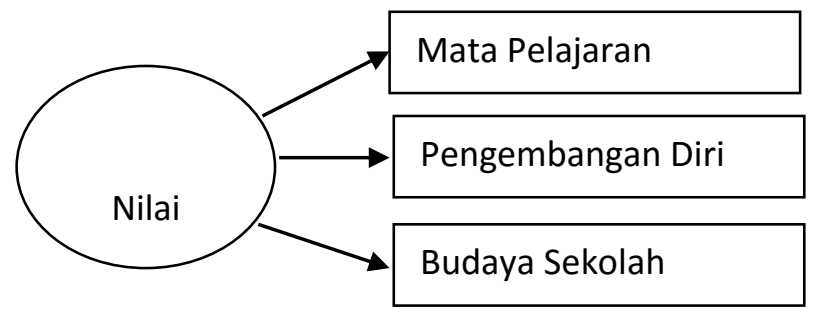

Maka dengan demikian muatan kurikulum Aflatoun dengan 8 buku kerja merupakan muatan kurikulum berkarakter yang disampaikan dalam kegiatan ekstrakurikuler dengan jalur pengembangan diri dan budaya sekolah.

Tujuan implementasi Program Aflatoun di beberapa lembaga penyelenggara di Madura adalah untuk memberdayakan anak-anak melalui sebuah pendekatan berimbang terhadap pendidikan sosial dan finansial anak.. Yaitu mengajarkan kepada anak tentang nilai-nilai karakter melalui kegiatan program Aflatoun.

Tujuannya ini seperti yang telah ditekankan oleh Aflatoun yaitu untuk mempedayakan anak. Bahwa anak-anak adalah mempunyai potensi untuk didaya gunakan. Potensi itu sangat besar, kompetensi mereka harus ditumbuhkan untuk meningkatkan harga diri anak, membantu anak mendapatkan gambaran diri yang positif melalui kesadaran diri dan penghargaan terhadap diri sendiri, menciptakan kesadaran atas hak-hak anak, membuat anak-anak peka terhadap kelompok anak terpinggirkan yang kebutuhannya tidak terpenuhi. Program Aflatoun dapat mewujudkan peserta didik mampu secara mandiri meningkatkan dan menggunakan pengetahuannya,

${ }^{50}$ Agus wibowo, Pendidikan Karakter....h. 71

${ }^{51}$ Ibid, h. 73 
mengkaji dan menginternalisasi nilai-nilai karakter dan akhlak mulia sehingga terwujud dalam prilaku sehari-hari.

Tujuan tersebut sejalan dengan Tujuan Pendidikan Nasional yaitu Pendidikan Nasional bertujuan untuk mengembangkan kemampuan dan membentuk watak serta peradaban bangsa yang bermartabat dalam rangkan mencerdasakan kehidupan bangsa, bertujuan untuk berkembangnya potensi peserta didik agar menjadi manusi yang beriman dan bertakwa kepada Tuhan Yang Maha Esa, berakhlak mulia, sehat, berilmu, cakap, kreatif, mandiri, dan menjadi warga Negara yang demokratis serta bertanggung jawab. ${ }^{52}$

Sementara tujuan pendidikan karakter yang diharapkan Kementerian Pendidikan Nasional ${ }^{53}$ adalah:

1. Mengembangkan potensi kalbu/nurani/afektif peserta didik sebagai manusia dan warganegara yang memiliki nilai-nilai budaya dan karakter bangsa. B. Mengembangkan kebiasaan dan perilaku peserta didik yang terpuji dan sejalan dengan nilai-nilai universal dan tradisi budaya bangsa yang religius.

2. Menanamkan jiwa kepemimpinan dan tanggung jawab peserta didik sebagai generasi penerus bangsa.

3. Mengembangkan kemampuan peserta didik menjadi manusia yang mandiri, kreatif, berwawasan kebangsaan; dan

4. mengembangkan lingkungan kehidupan sekolah sebagai lingkungan belajar yang aman, jujur, penuh kreativitas dan persahabatan, serta dengan rasa kebangsaan yang tinggi dan penuh kekuatan (dignity).

Pendidikan Karakter pada tingkat institusi mengarah pada pembentukan budaya sekolah, yaitu nilai-nilai yang melandasi prilaku, tradisi, kebiasaan keseharian, dan simbol-simbol yang dipraktekkan dalam semua warga sekolah dan masyarakat sekitar sekolah. Budaya sekolah merupakan ciri khas, karakter atau watak, dan citra sekolah tersebut di mata masyarakat luas.

Dengan demikian tujuan Implementasi Program Aflatoun dalam Pendidikan Karakter di lembaga penyelenggara telah sesuai dengan tujuan Pendidikan Karakter Nasional.

Target implementasi Program Aflatoun di lembaga penyelenggara sesuai dengan tujuan yang ingin dicapai yaitu membentuk pribadi anak yang berkarakter. Target tersebut dapat dilihat dari program semester aflatoun yaitu pada semester pertama, anak-anak Para siswa Aflatoun dapat menggambarkan diri secara positif melalui kesadaran diri dan menghargai diri sendiri serta

52 Undang-undang RI Nomor 20 Tahun 2003 tentang Sistem Pendidikan Nasional Bab II Pasal 3.

${ }^{53}$ Kementerian Pendidikan Nasional, Desain Induk Pendidikan ..... h. 9

Jurnal Pendidikan Agama Islam

Volume 3 Nomor 2 November 2015

ISSN: 2089-1946

Hal. 442 - 449 
mengetahui keunikan dalam dirinya. Dan para siswa memahami sumbangan penting dan unik yang diberikan setiap orang dalam masyarakat dan memahami nilai kemandirian. Berlaku jujur setelah mendengar cerita-cerita tentang kejujuran di kelas Aflatoun. Dan para siswa dapat bersikap menghargai dan menerima keunikan orang lain. Juga memahami hak dan tanggung jawab.

Pada semester kedua, Para siswa dapat bersikap peka terhadap sosial khususnya kepada anak-anak yang terpinggirkan yang kebutuhannya tidak terpenuhi. Para siswa dapat menekankan kembali pesan-pesan yang ada dalam buku/ kurikulum aflatoun. Dan tumbuh sikap positif untuk melakukan perubahan. Para siswa mampu menyadari perubahan yang terjadi dalam diri mereka. Dan para siswa dapat memahami bahwa dirinya mampu melakukan hal yang sama tetapi dengan cara yang berbeda.

Sementara taget pendidikan karakter yang diharapkan Kementerian Pendidikan Nasional ${ }^{54}$ adalah:

a. Peserta didik dapat mengembangkan potensi kalbu/nurani/afektif peserta didik sebagai manusia dan warganegara yang memiliki nilai-nilai budaya dan karakter bangsa.

b. Peserta didik dapat mengembangkan kebiasaan dan perilaku yang terpuji dan sejalan dengan nilai-nilai universal dan tradisi budaya bangsa yang religius.

c. Peserta didik dapat menanamkan jiwa kepemimpinan dan tanggung jawab sebagai generasi penerus bangsa.

d. Peserta didik dapat mengembangkan kemampuan menjadi manusia yang mandiri, kreatif, berwawasan kebangsaan; dan

e. Peserta didik dapat mengembangkan lingkungan kehidupan sekolah sebagai lingkungan belajar yang aman, jujur, penuh kreativitas dan persahabatan, serta dengan rasa kebangsaan yang tinggi dan penuh kekuatan (dignity).

Dengan demikian target implementasi Program Aflatoun dalam Pendidikan Karakter di lembaga penyelenggara susuai dengan target pendidikan karakter yang diharapkan oleh Kementrian Pendidikan Nasional.

18 nilai karakter yang ditetapkan oleh kementrian pendidikan hanya ada 8 target nilai karakter yang ditekankan dalam implementasi program Aflatoun dalam pendidikan karakter di lembaga penyelenggara. 8 nilai karakter tersebut adalah;

1. Religius

2. Harga diri dan mengetahui keunikan,

3. kemandirian,

${ }^{54}$ Kementerian Pendidikan Nasional, Desain Induk..... h. 9 
4. kejujuran,

5. hak dan tanggung jawab,

6. tanggung jawab sosial,

7. toleransi/menghormati perbedaan,

8. dan cinta tanah air.

Delapan nilai karakter yang ditekankan dalam implementasi program Aflatoun tersebut disampaikan dalam pembelajaran ekstrakurikuler dengan menggunakan 8 buku kerja Aflatoun. Pada semester pertama pembelajaran pada buku kerja satu s/d empat. Sementara pada semester kedua pembelajaran tentang buku kerja lima s/d lima.

Berikut penekanan nilai pada semester pertama adalah:

1. Buku kerja satu tentang : Harga diri dan mengetahui keunikan,

2. Buku kerja dua tentang : kemandirian,

3. Buku kerja tiga : kejujuran,

4. Buku kerja empat: tentang hak dan tanggung jawab sosial,

Kemudian penekanan nilai pada semester kedua adalah;

1. Buku kerja lima tentang : tanggung jawab sosial,

2. Buku kerja enam tentang : toleransi/menghormati perbedaan,

3. Buku kerja tujuh : religiusitas,

4. Buku kerja delapan: cinta tanah air.

Dalam hal ini, Aflatoun membenarkan adanya materi-materi kegiatan pembelajaran program Aflatoun yang disesuaikan dengan kebutuhan dan kemampuan lembaga penyelenggara program. Bahwa penyelenggara program Aflatoun berhak melakukan penyesuaian dengan peraturan yang ada di sekolah.

Sementara sasaran implementasi program Aflatoun di lembaga penyelenggara adalah siswa yang berumur $13 \mathrm{~s} / \mathrm{d} 14$ tahun yaitu siswa dan siswi yang duduk di kelas VII. Rekrutmen Peserta Aflatoun ini dilakukan dan dibuka kepada kepada seluruh siswa yang berminat dan ingin mengembangkan potensi dirinya.

Mengenai sasaran ini, guru ditemukan kendala-kendala yaitu; terjadi kendala dalam rekrutmen peserta anggota kelompok aflatoun. Yaitu pada faktor umur anak. Umur anak akan sangat berpengaruh kepada efektivitas pembelajaran. Karena setiap buku kerja Aflatoun itu ada spesifikasi umur. Misalnya buku kerja satu, diperuntukkan kepada anak umur 6 s/d 7, buku kerja dua untuk anak umur 8 s/d 9 dan seterusnya. Sementara anak-anak MTs di sini rata-rata berumur 13,14 dan 15 tahun. Ini yang membuat kami harus melakukan pemilihan materi pembelajaran, sehingga semua buku kerja Aflatoun dapat diajarkan pada anak-anak. 
Namun hal ini dapat diatasi dengan penyelenggaraan kegiatan dengan tetap menggunakan kedelapan buku kerja tersebut dan telah dilakukan pemilihan materi dan nilai karakter yang menjadi target madrasah.

Adapun nilai pendidikan karakter yang dikembangkan Kementerian Pendidikan ada delapan belas karakter. Nilai-nilai tersebut bersumber dari agama, pancasila, budaya, dan tujuan pendidikan nasional. Adapun delapan belas nilai tersebut yaitu: religius, jujur, toleransi, disiplin, kerja keras, kreatif, mandiri, demokratis, rasa ingin tahu, semangat kebangsaan, cinta tanah air, menghargai prestasi, bersahabat/komunikatif, cinta damai, gemar membaca, peduli lingkungan, peduli sosial, dan tanggung jawab. ${ }^{55}$

Meskipun telah terdapat 18 nilai pembentuk karakter bangsa, namun satuan pendidikan dapat menentukan prioritas pengembangannya dengan cara melanjutkan nilai prakondisi yang diperkuat dengan beberapa nilai yang diprioritaskan dari 18 nilai di atas.

Dengan demikian Program Aflatoun di lembaga penyelenggara menentukan prioritas dengan menekankan nilai pendidikan karakter kepada delapan nilai. Nilai-nilai yang ditekankan dalam program Aflatoun jika dikomparasikan dengan nilai karakter Nasional akan terlihat sebagaimana berikut :

Peniliaian nilai terhadap keberhasilan implementasi program Aflatoun dalam pendidikan siswa dilakukan dengan cara pengamatan dengan menggunakan lembar pengamatan yang dilakukan setiap minggu. Obervasi dan pengamatan ini dilakukan langsung oleh guru Aflatoun dengan dibantu oleh guru-guru yang lain yang ikut melaporkan kepada guru aflatoun. Hasil laporan itu dilaporkan kepada Kepala sekolah pada tiap semester.

Penilaian dilakukan dengan pengamatan secara lansung terhadap perubahan yang terjadi dalam diri anak. Pengamatan itu dilakukan setiap minggu dimana pihaknya melihat dan mengamati kepribadian anak. Apabila terjadi pelanggaran disiplin di sekolah yang dilakukan oleh anak, guru Aflatoun secara langsung memberikan arahan dan pencerahan, supaya tidak terjadi nilai-nilai yang tidak diinginkan.

Hasil penilaian secara khusus dilakukan pada delapan nilai pendidikan karakter yang ditekankan yaitu ;

1. Religiusitas, bahwa para siswa mampu menyadari perubahan yang terjadi dalam diri mereka. Dan semakin dekat pada penciptanya serta hidup rukun.

55 Pusat Kurikulum, Pengembangan.... h. 9-10. 
2. Harga diri dan mengetahui keunikan, bahwa para siswa Aflatoun mampu menggambarkan diri secara positif melalui kesadaran diri dan menghargai diri sendiri serta mengetahui keunikan dalam dirinya.

3. kemandirian, bahwa para siswa memahami sumbangan penting dan unik yang diberikan setiap orang dalam masyarakat

4. kejujuran, bahwa para siswa berlaku jujur setelah mendengar cerita-cerita tenang kejujuran di kelas Aflatoun.

5. hak dan tanggung jawab, bahwa para siswa dapat bersikap menghargai dan menerima keunikan orang lain. Juga memahami hak dan tanggung jawab

6. tanggung jawab sosial, bahwa para siswa dapat bersikap peka terhadap sosial khususnya kepada anak-anak yang terpinggirkan yang kebutuhannya tidak terpenuhi.

7. toleransi/menghormati perbedaan, Para siswa dapat menekankan kembali pesan-pesan yang ada dalam buku/ kurikulum aflatoun. Dan tumbuh sikap positif untuk melakukan perubahan

8. dan cinta tanah air. Bahwa para siswa dapat memahami bahwa dirinya mampu melakukan hal yang sama tetapi dengan cara yang berbeda. Dan cinta kepada tanah air.

Dengan demikian dalam melakukan penilaian keberhasilan program, telah mengikuti Langkah-langkah yang diatur dalam Kemendiknas, bahwa langkah-langkah tersebut di antaranya adalah :

1. Menetapkan indikator dari nilai-nilai yang ditetapkan atau disepakati.

2. Menyusun berbagai instrument penilaian.

3. Melakukan pencatatan terhadap pencapaian indikator.

4. Melakukan analisis dan evaluasi.

5. Melakukan tindak lanjut.56

\section{E. Penutup}

Program Aflatoun yang menawarkan sebuah pendidikan berimbang terhadap pendidikan sosial dan finansial mendapat Animu besar masyarakat khususnya stakeholder dari lembaga pendidikan dalam mengimplentasikan program ini. Metode implementasinya yang fleksibel dapat dengan mudah diterapkan di sekolah-sekolah dan Pesantren.

Sebuah penelitian menunjukkan adanya asistensi dan value supply kurikulum aflatoun terhadap Kurikulum Nasional. Beberapa catatan penting hasil penelitian tersebut adalah metodelogi impelementasi aflatoun, bahwa program ini selain dapat diselenggarakan di kelas dalam kegiatan belajar mengajar, dapat diintegrasikan dengan materi pelajaran di kelas, program

\footnotetext{
${ }^{56}$ Agus Wibowo, Pendidikan.........h.98.
} 
Aflatoun ini juga dapat diselenggarakan dalam kegiatan ekstrakurikuler. Kemudian Pelaksanaan program ini disampaikan dengan pendekatan dan metode pembelajaran fun learning.

Metode pembelajaran fun learning yang diterapkan pada program Aflatoun ini telah sesuai dengan metode yang dikembangkan oleh Kementrian Pendidikan dan Kebudayaan Nasional dalam pengembangan kurikulum 2013 yaitu proses pembelajaran yang mengedepankan pengalaman personal melalui observasi (menyimak, melihat, membaca dan mendengar) yang berpusat kepada peserta didik (student's centered and active learning) dengan sifat pembelajaran yang kontekstual. Dengan beberapa metode seperti metode bercerita, problem solving, reflective thinking/critical thinking, group dynamic, community building, responsibility building, picnic, camping study, kerja individu dan kelompok

Adapun nilai pendidikan karakter yang dikembangkan Kementerian Pendidikan ada delapan belas karakter. Nilai-nilai tersebut bersumber dari agama, pancasila, budaya, dan tujuan pendidikan nasional. Adapun delapan belas nilai tersebut yaitu: religius, jujur, toleransi, disiplin, kerja keras, kreatif, mandiri, demokratis, rasa ingin tahu, semangat kebangsaan, cinta tanah air, menghargai prestasi, bersahabat/komunikatif, cinta damai, gemar membaca, peduli lingkungan, peduli sosial, dan tanggung jawab.

Kedelapan belas nilai karakter tersebut juga menjadi target program aflatoun yang disain pembelajarannya menggunakan delapan buku kerja aflatoun. delapan buku kerja tersebut diajarkan sesuai jenjang dan umur peserta didik.

Jika Program Aflatoun ini diterapkan di sekolah maka diharapkan dapat memberikan tawaran baru dalam menyelesaikan problem krisis kemansiaan yang ada di bumi Nusantara.

\section{F. Daftar Pustaka}

Al-Alayali, Abdullah dan Hasan, al-Amien, saayyid, Munjid fi al-A'lam, Bairut: Darul Masyriq, Cet. 23. 1998.

Billimoria, Jeroo Partner manual, T.t.p.T.p. 2005

Ballou, William Giller Stephen Vaughn, Form and style: These, Report, terms paper, cet.1 Boston: Houghton Mifflin company,1989

Departemen Pendidikan dan Kebudayaan, Kamus Besar Bahasa Indonesia, Jakarta: Balai Pustaka, 1996

Daryanto \& Darmiatun, Suryatri, Implementasi Pendidikan Karakter di Sekolah, Yogyakarta: Gava Media, 2013

Fananie, Zainuddin, Pedoman Pendidikan Modern, Solo : Tinda Medina, 2011 
Mufiqur Rahman

Handoyo, Eko \& Tijan, Model Pendidikan Karakter, Semarang:Widya Karya Press, 2010

Kementerian Pendidikan Nasional, Desain Induk Pendidikan Karakter Kementerian Pendidikan Nasional, Jakarta, 2010a

Kesuma, et. al., Pendidikan Karakter: Kajian Teori dan Praktik di Sekolah, Bandung: PT. Remaja Rosdakarya, 2011

Kementerian Pendidikan Nasional, Kebijakan Nasional Pembangunan Karakter Bangsa, Jakarta, 2010e

Kementrian Pendidikan Nasional, Pengembangan Budaya dan karakter bangsa. Bahan pelatihan penguatan metodelogi Pembelajaran berdasarkan nilainilai budaya untuk membentuk daya saing dan karakter bangsa. Jakarta: Kemendiknas, 2010

Kementrian Pendidikan Nasional, Pedoman pelaksanaan pendidikan (berdasarkan pengalaman di santuan pendidikan rintisan), Jakarta: Kemendiknas badan penelitian dan pengembangan pusat kurikulum dan pembukuan, 2011

M.W, Berkowitz, and Melinda, C, Bier, What Works In Character Education: A Research-driven guide for educators, Washington, DC Univesity of Missouri-St Louis. 2005

Mardianto, Teknik pengelompokan siswa, Medan: IAIN Press, 2013

Manual Evaluasi Aflatoun, Jakarta: Lekdis Nusantara, Lembaga Kajian Pendidikan, Keislaman dan sosial Nusantara, 2008

Manual pelatihan Aflatoun, Jakarta: Lekdis Nusantara, Lembaga Kajian Pendidikan, Keislaman dan sosial Nusantara, 2008

Pusat Kurikulum Balitbang Kemdiknas, Pengembangan dan Pendidikan Budaya \& Karakter Bangsa: Pedoman Sekolah, Jakarta: Puskur Balitbang Kemdiknas, 2009

Rosinta, S, Efektivitas Pengelolaan dalam Pengembangan Kreativitas Anak Usia Dini, Medan: UNIMED, 2005

Raka, Gede, et. al., Pendidikan Karakter di Sekolah : dari gagasan ke tindakan, (Jakarta: PT Alex Media Komputinduo Kelompok Gramedia, 2011

Sekretariat Aflatoun, Manual Evaluasi Aflatoun, Jakarta: Lekdis Nusantara, Lembaga Kajian Pendidikan, Keislaman dan sosial Nusantara, 2008

Sekretariat Aflatoun, "Aflatoun Programme Note" dalam Aflatoun journal 20 September 2012

Sekretariat Aflatoun Indonesia, Manual Evaluasi Aflatoun, terj. Lapis (Program for Islamic school supported by Australian Governmen.

Suryadi, "Aflatoun Berjuang Cerdaskan Anak Negri” dalam Harian Radar Madura (Jawa Pos Group), 19 Maret 2013 
Suryadi, Juknis Pelaksaan Pelatihan Program Aflatoun untuk guru SD \& Mts di Medan tahun 2012 (buku, tidak diterbitkan)

Sumahami Jaya, Suparman et. al.,Pendidikan Karakter Mandiri dan Kewiraswataan, Bandung: Angkasa, 2002

Tim Redaksi, Kamus Besar Bahasa Indonesia Jakarta: Balai Pustaka, Edisi Ketiga. 2001

Tim Aflatoun, The Aflatoun Series Book \#1, Terj. LAPIS, Seri Aflatoun Buku 1 Jakarta: Lekdis Nusantara, 2008 , The Aflatoun Series Book \#2, Terj. LAPIS, Seri Aflatoun Buku 2, Jakarta : Lekdis Nusantara, 2008 The Aflatoun Series Book \#3, Terj. LAPIS, Seri Aflatoun Buku 3, Jakarta : Lekdis Nusantara, 2008 The Aflatoun Series Book \#4, Terj. LAPIS, Seri Aflatoun Buku 4, Jakarta : Lekdis Nusantara, 2008 The Aflatoun Series Book \#5, Terj. LAPIS, Seri Aflatoun Buku 5, Jakarta :

Lekdis Nusantara, 2008 The Aflatoun Series Book \#6, Terj. LAPIS, Seri Aflatoun Buku 6, Jakarta : Lekdis Nusantara, 2008 The Aflatoun Series Book \#7, Terj. LAPIS, Seri Aflatoun Buku 7, Jakarta : Lekdis Nusantara, 2008 The Aflatoun Series Book \#8, Terj. LAPIS, Seri Aflatoun Buku 8, Jakarta : Lekdis Nusantara, 2008

Undang-undang Sisdiknas, Sistem Pendidikan Nasional, Bandung: Fokusindo Mandiri, cet. Januari, 2012

Wibowo, Agus, Pendidikan Karakter: Strategi Membangun Karakter Bangsa Berperadaban, Yogyakarta: Pustaka Pelajar, 2012

\section{Website}

http://www.architectsofpeace.org/architects-of-peace/jeroobillimoria?page=2.

diakses Jumat 25 Oktober 2013 pukul 18.30 WIB

http://www.skollfoundation.org/entrepreneur/jeroo-billimoria/. diakses Jumat 25 Oktober 2013 pukul 18.30 WIB

http://www.aflatoun.org/programme/programme-selected/curriculum, diakses hari Jumat 25 Oktober 2013 pukul 18.30 WIB

http://www.aflatoun.net/curriculum, diakses hari Selasa, 29 Oktober 2013 pukul 19.30 WIB

http://www.aflatoun.org/story/story-selected/aflatoun-comes-from, diakses Jumat 25 Oktober 2013 pukul 18.30 WIB

http://www.aflatoun.org/story/story-selected/dream-and-goal, diakses hari kamis 22 Novemer 2013 pukul $19.40 \mathrm{WIb}$ 